\title{
Exploring the interplay between Framing and Securitization theory: the case of the Arab Spring protests in Bahrain
}

\author{
Explorando a interação entre Enquadramento e a \\ teoria de Securitização: o caso dos protestos da Primavera \\ Árabe em Bahrain
}

http://dx.doi.org/10.1590/0034-7329201400109

VÂNIA CARVALHO PINTO*

Rev. Bras. Polít. Int. 57 (1): 162-176 [2014]

\section{Introduction}

This article proposes to explore the theoretical interplay and complementarity between securitization theory and the framing approach, a research intersection that had been already apparent to those of us who work on framing, but to which Scott Watson's 2012 Millennium article gave an added boost.

In the present article, I will engage with Watson's proposal to further the integration of both theories as I agree that their extensive overlapping does open an interesting and potential fruitful examination path (Watson 2012, 301). I will focus on what framing has to offer to securitization theory in terms of investigating a given audience's preferences. The main idea is to show the ways by which the framing approach can be integrated into the general framework of securitization so as to sharpen the latter's guidelines for application in a more precise and all-inclusive way. ${ }^{1}$ The analytical focus is on the reworking of the "felicity conditions" for a successful securitization, since they bear close similarity to the criteria of the framing approach. To the resulting product, I call security framing.

In engaging with this method of examination, I am aware of the many formulations to framing that can be found in the literature, which also spans a variety of disciplines. In this text I explicitly engage with the analytical scheme

* University of Brasília, Brasília, DF, Brazil (vcp.unb@gmail.com).

1 The necessity of sharpening the guidelines for the investigation of securitization processes is an outstanding issue within the securitization studies agenda. Many authors have endeavored to advance this research goal by engaging with multiple sides of securitization theory. See, for example, Lene Hansen (2011) for a post-structuralist perspective, and Roxanna Sjöstedt (2013) on the role of identities for the internalization of threats. 
proposed by Robert Benford and David Snow (1986), within the context of social movements research, a research choice that I will justify later in the article.

The insights that incorporating framing into the study of securitization processes can bring about will be demonstrated as regards the case of the prodemocracy protests in Bahrain that have been raging as part of the Arab Spring. This is quite an interesting case study for the examination of securitization processes, since several of them occurred in tandem, initiated not only by the government but also by civil society actors. Protesters as well as TV stations such as al-Jazeera and Bahrain's state TV made their own attempts at securitization. In these cases, and as a result of existing censorship and the authoritarian nature of the Bahraini regime, images and bodily performances, rather than words, have often "spoken" security. ${ }^{2}$ The same way that there were a number of securitizing actors trying to initiate their own processes, there were also several audiences to which these were targeted. In simple terms, there was clearly a national and an international audience, although neither is monolithic and focusing on the several sub-audiences within each category would prove to be a herculean task. Within the international audience assembly there was a clear target group that has shown to be the most relevant in terms of how events unfolded in Bahrain: the countries of the Gulf Cooperation Council (GCC). ${ }^{3}$ The Bahraini government successfully securitized the manifestations to its neighboring countries rendering it the only example within the Arab Spring where there was an official request for foreign military intervention to help control the protests. It also ended up serving as an important illustration of the regional Gulf dynamics in the post-Arab Spring context. The temporal focus for this analysis will be from early 2011 until August 2013 — coinciding with the end of President Mahmood Ahmadinejad's term-, a time during which tensions between Iran and the Gulf monarchies over Bahrain were higher. Since current Iranian President Hassan Rohani has been trying to lower tensions in the Gulf, there have been fewer high-profile disputes.

This article seeks to make a double-pronged contribution: firstly, to add to a greater theoretical combination between framing and securitization by showing the ways the latter may benefit from the theoretical insights of the first; and secondly to further the application of securitization to cases outside of Europe ${ }^{4}$ as a means to help explain relevant events of the international arena.

The argument proceeds as follows: the first section introduces the framing approach; the second presents the articulation between the latter and securitization, which I term "security framing"; and the third applies this framework to Bahrain. The article finishes with a summing up of the argument.

2 On the power of images in processes of securitization, see Lene Hansen (2011) and Michael Williams (2003).

3 Founded in 1981, the GCC comprises all of the monarchies of the Arabian Peninsula such as Saudi Arabia, United Arab Emirates (UAE), Kuwait, Qatar, Oman, and Bahrain. It came into existence in the midst of the First Gulf War (1980-1988) opposing Iran and Iraq.

4 See, for example, Claire Wilkinson's (2007) work on Kyrgyzstan. 


\section{Framing as an analytical instrument}

The same way that securitization theory has been popular within the broad field of security studies, the framing approach has also enjoyed widespread acceptance within the social sciences. First used in psychology of communication, the concept of Frame was later imported into sociology by Erving Goffman, as a means to explain everyday interactions and communicative acts. He defined frame as a "schemata of interpretation" that enables individuals "to locate, perceive, identify, and label" occurrences within their life space and the world at large (Goffman 1974, 2). ${ }^{5}$

Framing is an associated but slightly different concept. It refers to the "signifying work," on which leaders engage, by which "relevant events and conditions" are displayed "in ways that [...] intend to mobilize potential adherents and constituents, to garner bystander support and to demobilize antagonists" (Snow and Benford 1988, 198). Framing, therefore, is a dynamic process of meaning assignment that aims at organizing the audience's experience into interpretative frames, and guide their action so as to fulfill the objectives outlined by the strategic actor (Snow et al. 1986, 464).

The utilization of this approach, in both descriptive and analytical ways, has been found to be a particularly useful research instrument in a variety of disciplines, especially international relations ${ }^{6}$ and public policy scholarship. Indeed, one of the reasons for this overall acceptance, among several others, is that the application of this approach entails paying renewed attention to ideas and the role that their interpretation plays in explaining individual (and collective) mobilization patterns (see Snow and Benford 2000, 611; Hajer and Laws 2008, 256-259). Since the theory focuses on individual event interpretation, i.e. the preferences of the audience, it allows for the establishment of a connection between certain events and the meanings people attach to them (Snow and Benford 1988, 197-198; Noakes and Johnston 2005, 3).

This means that this framework can be applied to any situation whereby an actor tries to convince a given audience (or a target group) to participate $\mathrm{in} / \mathrm{mobilize}$ for and/or believe in a certain idea. This is a basic premise that can be applied to a vast myriad of situations. Claudia Derichs (2004), for example, used the framing approach to study the nation-building process of the Malaysian state. At the core of her reasoning was the insight that the idea of nation and of national identity promoted by the state "is not something that grows naturally, but rather something that is strategically planned, defined, and produced" (Derichs 1999, 3).

5 For a review of the history of the concept, see Noakes and Johnston (2005, 1-32).

6 For a further application of the framing approach, albeit in a different formulation, to the relationship between countries, see Carvalho Pinto (2013) on the strategic partnership between Brazil and the Arab countries. 
This perspective can be equally applied to the study of the ways a state has constructed a certain notion of womanhood so as to foster generalized acceptance of the gender regime it promotes (see Carvalho Pinto 2012a). In this case, the scope of analysis expands from the social movement to the relationship between states, as one (Bahrain) tries to convince the others (GCC) to support its policies.

Therefore, since framing invests thoroughly on scrutinizing the audience's preferences, it can be of great usefulness in the study of a number of areas that are currently under-theorized in securitization studies. These include issues such as audience acceptance, non-linguistic communicative forms, empowerment, and marginalization, as well as resistance and desecuritization (Watson 2012, 279). This article does not claim to fulfill all such ambitious goals, but merely to advance towards issues of audience acceptance, as elaborated bellow.

\section{The criteria of Security Framing}

Transferring the ideas above to securitization theory, since framing refers to the way social movement leaders produce and assemble interpretative packages as regards certain events or problems, it resonates deeply with the "work" that is performed by the securitizing actor. The way a social movement leader, or in this context, a securitizing actor "produces" this package does provide significant clues as regards the successes or failures of mobilization and participation (Noakes and Johnston 2005, 7), and by implication in the success or lack thereof of the securitization process.

Similarly to securitization, the process of framing entails looking for ideational elements within the cultural universe of the target group (values, beliefs, ideologies and the like) that can present the issue at hand in ways that may lead to successful mobilization and participation (Snow and Benford 2005, 209). In doing so, the securitizing actor will frame the issues in a manner which could be easily accessible for the majority of the audience, with ideas and terminology formulated in terms easy to grasp. The acceptance of the framing (or the existential threat) will depend on the extent to which the target audience sees that explanation as meaningful and plausible, i.e. the degree to which the felicity conditions are fulfilled. These are: 1) the internal logic of the speech securitization act; 2) the securitizing actor must be considered to have the necessary authority to speak security on the matter-which connects with the legitimacy issue; and 3) a connection between the existential threat and historical/cultural associations with danger and harm that may aid the audience in making this association (Peoples and Vaughn-Williams 2010, 79). As can be seen in Table 1, these conditions bear close resemblance to the framing criteria as advanced by Snow and Benford. 
Table 1 . The security framing criteria.

\begin{tabular}{|c|c|c|c|}
\hline \multicolumn{4}{|c|}{ Securitizing Actor $\rightarrow$ Existential threat $\rightarrow$ Audience } \\
\hline & Dimensions & Criteria & Definitions \\
\hline \multirow{6}{*}{$\begin{array}{l}\text { Resonance } \\
\text { (felicity } \\
\text { conditions) }\end{array}$} & \multirow[t]{3}{*}{ Credibility } & Consistency & $\begin{array}{l}\text { Logical articulation of constitutive } \\
\text { elements }\end{array}$ \\
\hline & & Empirical credibility & $\begin{array}{l}\text { Connection with existing problems } \\
\text { as perceived by the target group }\end{array}$ \\
\hline & & Credibility of the articulator(s) & $\begin{array}{l}\text { Legitimacy accorded to the } \\
\text { proponent }\end{array}$ \\
\hline & \multirow[t]{3}{*}{ Salience } & Centrality & $\begin{array}{l}\text { Degree of importance it assumes } \\
\text { within the value system of the } \\
\text { target group }\end{array}$ \\
\hline & & Experiential commensurability & $\begin{array}{l}\text { Connections to the worldview of } \\
\text { the target group }\end{array}$ \\
\hline & & Narrative fidelity & Cultural resonance \\
\hline
\end{tabular}

Source: Snow and Benford (2000, 611-639), Derichs (2004, 67), compiled by the author.

It develops as follows: the securitizing actor's construction of an existential threat as regards a referent object must contain certain elements that convince the audience to move that subject from the realm of normal politics into one of extraordinary measures. In order to do so, the constructed threat must possess resonance among the target group (or audience). This means that the message must possess credibility and salience, two key resonance criteria. As regards credibility, the message must possess consistency-meaning that the arguments conveyed must make logical sense_ and empirical credibility—i.e. to be in line with the audience's perceived problems-, and lastly the securitizing actor must be credible in the eyes of the audience. This means that the target group must recognize legitimacy to the articulator of the message to delineate this kind of threat. If a university professor went on TV to state that Brazil was going to be militarily attacked, nobody would believe them given their position as a university professor. However, if the President delivered a similar message, the reception would be quite different, for the population would recognize the legitimacy of the President to talk about such matters.

The second resonance criterion-salience-is also quite important for the success of the securitization process. It includes the degree of importance the issue holds in the hierarchy of concerns of the target group (centrality), how it connects to the audience's vision of the world (experiential commensurability), and finally how it relates to the audience's narratives, myths, and basic assumptions. On occasion there is a certain overlapping between the concepts but it makes 
analytical sense to try to differentiate them from one another as much as possible. What follows is the application of these criteria to the case study at hand.

\section{Security framing the Arab Spring protests in Bahrain}

\section{On Bahrain}

Bahrain is a small island kingdom in the Arabian Gulf. Surrounded by other Gulf monarchies, such as Saudi Arabia, Kuwait, Qatar, Bahrain, Oman, and the United Arab Emirates, these countries are usually known for their oil wealth and their political system based on the principle of tribal hereditary monarchy (with the exception of Yemen, an oil-poor republic). The Gulf countries have many structural factors in common: a past of pre-oil extreme poverty, illiteracy, and a hard subsistence life in the desert, as well as royal families that have been ruling their respective regions for about 200 years. $^{7}$ All of the Gulf countries experienced varying degrees of popular protest and dissent that were already explored in a variety of publications (see Davidson 2012). In Bahrain, nevertheless, social agitation reached degrees that were not seen in the remaining gulf monarchies. If in countries like the UAE or Oman popular protest was limited both in scope and in demands, in Bahrain they were fiercely anti-system.

Traditionally, Bahraini society was relatively open compared to other gulf states. Since it started developing earlier, it featured a more publicly engaged and educated population. There had been intermittent political protests on and off since the country's independence and before recent events, the last serious ones were in the 1990s. Featuring a Sunni royal family in a Shiite-majority country, the population always accused the government of favoring the Sunni minority both socially and in the access to jobs. A further accusation that is leveled against the government is the alleged attempt to alter the religious makeup of the country by awarding nationality to Sunni Arabs from other parts of the Middle East and Asia, such as Yemenites and Pakistanis. It should also be mentioned that about two thirds of the population are under thirty years of age and that unemployment ranges the 30\% (International Crisis Group 2011).

\section{The demonstrations}

The protests began in February 2011 in the Pearl roundabout, a central location in the country's capital, Manama. The demonstrators formed quite a heterogeneous group, with young and old, Sunnis and Shiites, as well as professional and political groups. As always in such gatherings, the demands varied, ranging from the expansion of political rights until the fall of the monarchy. As time went

7 For more information about the histories of these countries, see Zahlan (1998). 
by and attempts at political dialogue between the government and the opposition faltered, the manifestations were increasing in size and voices demanding for the end of the al-Khalifa rule became louder. The reasons that underlined these demonstrations were the same as in other Arab countries: better life conditions, expansion of political rights with a limitation to the power of the ruling family, as well as an end to the perceived anti-Shiite policies of the Bahraini government (Davidson 2012, 205-208).

Within this context, the Bahraini king securitized the manifestations. Taking the sovereignty of Bahrain as the referent object (and by implication of the other Gulf monarchies), he delineated an existential threat to the country's national integrity (and of the Gulf states). The threat was Iran, who was trying to destabilize Bahrain by inciting the Shiite masses to rebel against the government. His speech act was asking his neighbors for help in controlling the manifestations and in allowing rising levels of violence to take hold. The securitization scheme is shown in Figure 1.

\section{Securitizing actor: Bahraini King}

Existential threat: Iran/Shiites

Referent object: Bahrain/Gulf monarchies

Speech act: Asking for foreign military intervention

Audience: GCC countries

Figure 1. Securitization scheme in Bahrain manifestations.

On March 14, 2011, troops from the GCC countries, operating under an agreement called Peninsula Security Shield, entered Bahrain. They were made of 1,000 Saudis, 500 Emiratis, and a small number of Qataris. The overall situation in the country was securitized and the King imposed extraordinary measures. $\mathrm{He}$ declared a national emergency state with partial curfew, the banning of protests and the expansion of military power. This was accompanied by an increase in violence and the imprisonment of opposition leaders (Carvalho Pinto 2012b). The fact that the GCC countries sent troops shows that the process of securitization had resonance among them, as the application of the security framing approach will illustrate.

\section{The frame of existential threat}

The existential threat presented by the Bahraini king to the GCC allies (and likewise to the population) relied basically on the same premises. It was an 
Iranian plot, whereby the latter would incite the Shiite masses in other countries to rebel and provoke the fall of the Sunni regimes. It should be noted that for this argument to work, Shiites' loyalty to Iran-irrespective of their nationality or country of residence-had to be presumed, which points to the success of both criteria of experiential commensurability and narrative fidelity among the audience. Consequently, the overall argument had consistency mainly because of Bahrain's (and other Gulf countries') difficult relationship with Iran and of the historical animosity between Sunnis and Shiites, two important points that explain the success of this securitization.

\section{Explaining the audience's acceptance: credibility \& salience}

Bahrain is not the only country that has difficult relations with Iran. Relations with the other Gulf monarchies, particularly Saudi Arabia and the United Arab Emirates, are similarly strained. In 1971, year of Bahraini independence (as well as of Qatar and the UAE), Iran was still a monarchy governed by the Pahlavi dynasty and the Iranian Revolution was still eight years away. At the time, displeased with the move to create wealthy microstates in the Gulf, the Shah Reza Pahlavi declared that the formation of new countries in its regional area of influence constituted an imperial plot in order to impair Iranian hegemony in the Gulf (quoted in Davidson 2008, 64). Part of this argument was that Bahrain was actually part of Iran since it had belonged to the Persian Empire. The matter was solved with the sending of a United Nations delegation to Bahrain in 1970 in order to inquire about the population's national preferences. They manifested themselves overwhelmingly as Bahraini and the latter's independence was therefore assured. Disturbed with the "loss" of Bahrain, the Shah decided to occupy three small islands that belonged to the UAE—Abu Musa and Greater and Lesser Tunbs-in 1971, eve of the country's independence (Carvalho Pinto 2012b). Iran still holds on to these islands and this problem has since become a very thorny issue looming over bilateral relations (empirical credibility).

In the years following the 1979 Iranian revolution, relations between the Gulf monarchies and Iran deteriorated significantly. This was due essentially to the strong anti-monarchy ethos of the revolution. Internally considered as a victory of the oppressed masses against a despotic and amoral ruler, the new republican regime sought to export the revolution to other parts of the world, particularly to their neighboring countries, so as to serve as inspiration for the oppressed masses in the fight against dictators. The anti-monarchical and revolutionary character of the new Iranian government, the only Shiite country in the region, scared the tiny neighboring monarchies, at the time with only eight years of independent existence, whose majority of the population was predominantly Sunni (Katouzian 2010, 35-53) (narrative fidelity). A few years later, in the midst of the First Gulf War, the monarchies formed a regional security organization, the Gulf Cooperation 
Council, whose main goal was to defend them against Iran (centrality/experiential credibility).

Fast-forwarding into the present, Iran and the Gulf monarchies, especially Saudi Arabia, still struggle for power and influence in the region. One of the most outstanding issues is the Iranian nuclear ambition. The rulers' thinking about the matter was made public with the release by Wikileaks of the diplomatic cables between the US and several Arab countries. The content of these documents clearly show the deep rift among the Gulf neighbors. In an article published by the German paper Der Spiegel in their English online edition, transcriptions were reproduced of the citations attributed to the Crown Prince of the UAE, Sheikh Mohammed bin Zayed al-Nahyan, to the former Egyptian president Hosni Mubarak, and to King Abdullah of Jordan. These include statements such as "Iranians are big liars," "Ahmadinejad is like Hitler," and "Bomb Iran or live with a nuclear Iran" (Smoltczyk and Zand 2010a). These statements provide an interesting background to the Gulf rulers' thinking about Iran's goals and behavior in the region. Indeed, they help explain why the rulers would be predisposed to believe that Iran was behind popular protests in Bahrain as a forward strategy to destabilize the region (centrality/experiential commensurability). It should be mentioned that none of the governments to whom these citations were attributed denied them (Smoltczyk and Zand 2010b) and that Iran accused the US of having fabricated these documents as a means to instill dissent in the region (CBS News 2010).

A further issue that has been straining Gulf relations is the occupation of the UAE Islands. This matter has resurfaced in recent years with the UAE vociferously defending its right to the Islands and holding Iran accountable for the occupation at every international forum (Khan 2013). Indeed, in 2012 at the height of tensions between Iran and its Gulf neighbors, former Iranian President Mahmood Ahmadinejad visited the Islands, the first ever by an Iranian president to the disputed territory. The Gulf governments described such visit as both a provocation and a violation of UAE sovereignty, with the latter even recalling their ambassador from Tehran in protest. Iran stated that it would be ready to respond by force to any threats to its territorial integrity, with Ahmadinejad declaring that "the armed forces and the army will inflict heavy regret and shame in case of any aggression against Iranian lands and interests" (centrality/experiential credibility). Indeed, tensions continued high as Ahmadinejad declared that historical records proved "the Persian Gulf is Persian" (Al Arabiya and Agencies 2012). This constitutes another source of rivalry among the neighbors: the naming of the Gulf, an area that lies to the east of Arab countries and west of Iran and extends for 970 kilometers from the Shatt $\mathrm{Al}$ Arab delta to the Strait of Hormuz. Iran and the Gulf monarchies have been locked in a bitter dispute over the name of the regional waterway. Historically known as Persian Gulf, in the past few years the Gulf monarchies have been promoting the use of the name "Arab Gulf," so as to underline the Arab and not the Persian character of the region. This dispute 
has already led to some diplomatic clashes, most notably at FIFA, when the latter decided to name the area as Persian Gulf. Since none of the six GCC federations were alerted about the move, it was felt as a shock. As a result, the GCC was planning to submit a formal protest describing this attitude as one that targets their Gulf identity (Toumi 2013) (narrative fidelity/experiential commensurability). Iran also feels quite strongly about the matter, having threatened legal action against Google for not naming the waterway separating Iran and the Gulf states as Persian Gulf. Other related events include the 2010 Iranian threat of barring airlines that used the term Arabian Gulf from Iranian airspace. In the same year, the second Islamic Solidarity Games were cancelled after Arab and Iranian organizers failed to agree on whether to describe the Gulf as Persian or Arabian on medals. In addition, when in 2004 the National Geographic Society decided to feature both terms in its world atlas edition, Iranians launched a huge internet offensive: anyone searching for the Arabian Gulf on Google found a website saying it did not exist (BBC News 2012).

Therefore, given the history of relations between Iran and the Gulf states, it made ideational, cultural and practical sense for the Gulf monarchs to believe that Iran could be trying to endanger Bahrain as a first step to destabilize the Arabian peninsula and eventually to overthrow their regimes. In addition, it did not help that, especially during the Presidency of Mahmood Ahmadinejad, frequent declarations came out of Iran stating that Bahrain belonged to them (al-Zahed and Jazaeri 2012) (centrality/experiential commensurability and credibility).

When the protests and revolutions dubbed as "Arab Spring" first began in late 2010 in Tunisia, former President Ahmadinejad declared his joy at the beginning of the revolutions in other parts of the Muslim world (Molavi 2011). According to him, finally, the rest of the region was catching up to Iranian's Islamic revolution. His attempt to take hold of the narrative did not really work; however, to those who saw the Arab protests as producing dangerous instability and who believed in Iran's intrinsic bad intentions, it was easier to accept the idea of a possible Shiite "threat" (experiential commensurability, centrality/narrative fidelity and empirical credibility). Therefore, preventing Bahrain's fall into Iran's orbit has been a key concern among Gulf monarchs as Bahrain's troubles could have a spillover effect and endanger other countries' regimes. For this reason, declarations that "the security of Bahrain is the security of the region" have abounded among Gulf rulers (Zacharia and Birnbaum 2011) (centrality). This same tough line was adopted within the Gulf countries that took unprecedented measures to deal with dissent. In the UAE, for example, these have included the eight-month-long

8 This is associated to the expression "Shiite Crescent" as referring to the rise of the Shiite masses in the Middle East, incited by Iran in a bid to claim power. King Abdullah of Jordan coined the term in 2005 in reference to the Shiite party's win at the Iraqi national elections. Given that Iraq was a country that despite its Shiite majority had always been ruled by Sunnis, to see a large and important country such as Iraq being ruled for the first time ever by Shiites obviously seems to have made an impact in the Jordanian King. 
imprisonment of five bloggers who criticized the lack of political freedoms, the withdrawal of nationality of seven Emiratis, the implementation of a compulsory security clearance to accede to promotions in the public sector as well as access to any government funding, and the house arrest of a member of the royal al-Qasimi household from Ras al-Kaimah. One of the most highly publicized measures was the very unfavorable official reception of a petition signed by 133 public figures asking for the expansion of political rights (see Davidson 2012).

Clearly the gulf monarchies feared that the protests in their respective countries, supposedly inspired by Shiites and incited by Iran, were the first step for a wave of political unrest in the region, which could potentially topple the existing regimes in the region (centrality). For the Bahraini government, to attribute the manifestations solely to Iranian influence was also a way to delegitimize the demands of the protesters and to justify the use of force both to internal and international audiences. Even though the Bahraini government has been trying since 2011 to project an image of return to normalcy, the demonstrations and arrests have been continuing (failed desecuritization). Therefore, pre-existing historical rivalries and suspicion between Shiites and Sunnis lent greater credibility to this narrative. Bahrain was thus perceived as another point of the Axis of the Shiite Crescent, with the revolution in Bahrain being the focal point for the fall of all of the Gulf monarchies. This perception was further aided by the fact that in countries such as Saudi Arabia, Iraq, and Kuwait, demonstrations were held in support of the Shiites ${ }^{9}$ (narrative fidelity/experiential commensurability and credibility/centrality).

\section{Credibility of the articulator}

The securitizing actor in this case was the Bahraini government and more specifically the Bahraini King. He does not classify the protests as being prodemocracy since he claims to have started those reforms about 10 years earlier. His explanation to the years-long unrest is Iranian influence and the determination of some to damage Bahraini national unity. Consequently, he refuses the label "Arab Spring" to classify events in his country (Smoltczyk and Mekhennet 2012). It is difficult to assess how fellow Gulf rulers view the Bahraini King since that implies access to personal information that is difficult to come by. However, surely the other monarchs did see that the King was in trouble and that in presenting his case as an Iranian plot he was furthering his cause to remain in power. Nevertheless, given that other rulers were also having similar problems, to take the route of believing that foreign interference rather than their legitimacy was at stake also benefited them.

9 For more information see Reuters (2011) on the protests in Saudi Arabia, Kareem (2011) on Kuwait and Arango (2011) on Iraq. 


\section{Conclusion}

Overall, it was shown that the framing approach can be successfully incorporated into securitization theory and that its criteria can be quite useful both in the investigation of the ideational elements that underlie the construction of threats and in the ascertaining of the audience's preferences.

The application of the security framing criteria to the case of the prodemocracy protests in Bahrain has illustrated the reasons why the GCC countries were willing to accept the Bahraini government's frame of existential threat. Through the application of the several criteria, it was shown that the frame had great success among the audience for it fulfilled all the associated benchmarks of salience and credibility. The frame had consistency for it logically articulated elements from the audience's worldview (experiential commensurability), cultural context (narrative fidelity) and existing problems (empirical credibility). In addition, given that what was perceived to be at stake was the maintenance of the Gulf monarchies, the issue had obvious centrality for the audience. They considered that if the Bahraini regime fell, that would embolden other Shiite groups to try to overthrow monarchical rule in the Gulf region.

Indeed, the historically difficult relations with Iran rendered more plausible for the GCC audience to accept that Iran had a stake in the Bahraini protests, as part of an overall strategy to destabilize the Gulf monarchies. The fact that Iran always had claims to Bahrain, occupies three Emirati islands, and pursues a strategy for regional hegemony by means of a nuclear program were all factors that further gave credibility and salience to the threat frame delineated by the Bahraini King and that justified the extraordinary measure of foreign military intervention.

\section{Bibliographic references}

Alrabiya and Agencies (2012). Gulf Arabs condemn Ahmadinejad's visit to UAE-claimed island as "provocation". Online. 17 April. Available at: http://english.alarabiya.net/ articles/2012/04/17/208320.html.

Arango, Tim (2011). "Shiites in Iraq Support Bahrain's Protesters". Online. 17 May. NYT. Available at: http://www.nytimes.com/2011/04/02/world/middleeast/02iraq.html?_r=0.

BBCnews (2012). "Iran 'to sue Google' for not labelling Gulf on world map”. Online. 17 May. Available at: http://www.bbc.com/news/world-middle-east-18108246.

Carvalho Pinto (2013). "Uma Parceria estratégica, inovadora e ousada? Rumo a uma clarificação conceitual," in A. Lessa e H. Altemani (orgs.) Parcerias estratégicas do Brasil: a dimensão multilateral e as parcerias emergente. BH: Argumentvm-Fino Traço, pp. 93-112.

(2012a). Nation-Building, State and the Genderframing of Women's Rights in the UAE (1971-2009). Reading: Ithaca $134 \mathrm{p}$.

(2012b). "A revolução que não começou: As particularidades da primavera Khaleeji”.

Ciência e Cultura, v. 64, p. 30-33. 
CBSNews (2010). "Iran Official: U.S. Fabricated WikiLeaks Cables.” Online. 12 May. Available at: http://www.cbsnews.com/stories/2010/12/04/world/main7118348.shtml.

Davidson, Christopher M. (2012). After the Sheikhs: The coming collapse of the GulfMonarchies. London: Hurst, 298 p.

(2008). Dubai: The Vulnerability of Success, New York: Colombia University Press, $376 \mathrm{p}$.

Derichs, Claudia (2004). Nationenbildung in Malaysia als strategisches Staatshandeln: Bemühungen um die Schaffung nationaler Identität. Hamburg: IFA, 249 p.

(1999), "Nation-building in Malaysia under Conditions of Globalisation". Duisburg Working Papers on East Asian Studies, No. 25. Duisburg: Institut für Ostasienwissenschaften. Online. Available at: http://www.oapol.uni-duisburg-essen.de/d/gruen25.htm.

Goffman, Erving (1974). Frame Analysis: An Essay on the Organization of Experience. New York: Harper \& Row, 586 p.

Hansen, Lene (2011). “Theorizing the image for Security Studies: Visual securitization and the Muhammad Cartoon Crisis”. European Journal of International Relations, vol. 17(1), pp. 51-74.

Hajer, Maarten and David Laws (2008), “Ordering through Discourse,” Michael Moran and Martin Rein and Robert E. Goodin (Eds.), The Oxford Handbook of Public Policy. Oxford: Oxford University Press, pp. 251-268.

International Crisis Group (2011). "Popular Protests In North Africa And The Middle East (III): The Bahrain Revolt”. Middle East/North Africa Report, № 105. Online. Available at: http://www.crisisgroup.org///media/Files/105-\%20Popular\%20Protests\%20in\%20North\%20 Africa $\% 20$ and $\% 20$ the $\% 20$ Middle\%20East $\% 20$-III-The\%20Bahrain\%20Revolt.ashx.

Katouzian, Homa (2010). "The Iranian Revolution at 30: The Dialectic of State and Society." Middle East Critique, 19(1), p. 35-53.

Khan, Taimur (2013). "Sheikh Abdullah calls on international community to press Iran over occupation of UAE islands". Online. The National, 29 September. Available at: http://www. thenational.ae/uae/government/sheikh-abdullah-calls-on-international-community-to-pressiran-over-occupation-of-uae-islands.

Molavi, Afshin (2011). "Invoking the Arab Spring, Iran rewrites its own history”. Online. The National, 6 April. Available at: http://www.thenational.ae/thenationalconversation/comment/ invoking-the-arab-spring-iran-rewrites-its-own-history\#ixzz2wQuhcGsO.

Noakes, John A. and Hank Johnston (2005). "Frames of Protest: A Road Map to a Perspective," in H. Jonhston and J. A. Noakes (Eds.) Frames of Protest: Social Movements and the Framing Perspective. Oxford: Rowan and Littlefeld, pp. 1-32.

Kareem, Mona (2011). "Shiaphobia Hits Kuwait". Online. Jadaliyya. 17 May. Available at: http://www.jadaliyya.com/pages/index/1603/shiaphobia-hits-kuwait-.

Peoples, Columba and Nick Vaughan-Williams (2010). Critical Security Studies. An Introduction. London; NY: Routledge, 192 p.

Reuters (2011). "Saudi Shi'ites protest, support Bahrain brethren”. Online. 16 March. Available at: http://www.reuters.com/article/2011/03/16/us-bahrain-saudi-protestsidUSTRE72F8ZB20110316. 
Smoltczyk, Alexander and Bernhard Zand (2010a). "A Quiet Axis Forms Against Iran in the Middle East." Online. Der Spiegel. 15 July. Available at: http://www.spiegel.de/international/ world/0,1518,706445,00.html.

(2010b). "Interview with Saudi Prince Turki bin Faisal: 'America's Credibility Is the Victim of These Leaks””. Online. Der Spiegel. 12 June. Available at: http://www.spiegel.de/ international/world/0,1518,733054-2,00.html.

Smoltczyk, Alexander and Souad Mekhennet (2012). "SPIEGEL Interview with the King of Bahrain: 'Arab Spring? That's the Business of Other Countries'”. Online. Der Spiegel, 13 February. Available at: http://www.spiegel.de/international/world/spiegel-interview-withthe-king-of-bahrain-arab-spring-that-s-the-business-of-other-countries-a-814915.html.

Snow, David and Robert D. Benford (2005). "Clarifying the Relationship between Framing and Ideology", John A. Noakes and Hank Johnston (Eds.). Frames of Protest. Social Movements and the Framing Perspective. Lanham: Rowman \& Littlefield, pp. 205-212.

(2000). "Framing Processes and Social Movements: An Overview and Assessment." Annual Review of Sociology, Vol. 26, pp. 611-639.

(1988), “Ideology, Frame Resonance, and Participant Mobilization,” Bert Klandermans and Hanspeter Kriesi and Sidney Tarrow (Eds.). International Social Movement Research, Vol. 1: From Structure to Action. Comparing Social Movement Research across Cultures. London: JAI, pp. 197-217.

Snow, David et al. (1986). "Frame Alignment Processes, Micromobilization, and Movement Participation.” American Sociological Review, Vol. 51, No. 4, pp. 464-481.

Sjöstedt, Roxanna (2013). "Ideas, identities and internalization: Explaining securitizing moves." Cooperation and Conflict, vol. 48 (1) pp. 143-164.

Toumi, Habib (2013). "GCC to protest 'Persian Gulf' name by Fifa." Online. Gulf News. 24 September. Available at: http://gulfnews.com/news/gulf/bahrain/gcc-to-protest-persiangulf-name-by-fifa-1.1234937.

Watson, Scott (2012). "Framing” the Copenhagen School: Integrating the Literature on Threat Construction. Millennium: Journal of International Studies, vol. 40 (2), pp. 279-301.

Williams, Michael C. (2003). "Words, Images, Enemies: Securitization and International Politics.” International Studies Quarterly, vol. 47, pp. 511-531.

Wilkinson, Claire (2007). “The Copenhagen School on Tour in Kyrgyzstan: Is Securitization Theory Useable Outside Europe?” Security Dialogue, vol. 38 (5), pp. 5-25.

Zacharia, Janine and Michael Birnbaum (2011). "Saudis warn they will back Bahrain's king”. Online. The Age. 22 February. Available at: http://www.theage.com.au/world/saudis-warn-theywill-back-bahrains-king-20110221-1b2gb.html.

Al-Zahed, Saud and Elia Jazaeri (2012). "Iran's Khamenei-run newspaper calls for Bahrain annexation after GCC union talks". Online. Al-Arabiya, 16 May. Available at: http://www. alarabiya.net/articles/2012/05/16/214457.html.

Zahlan, Rosemarie (1998). The Making of the modern Gulf States: Kuwait, Bahrain, Qatar, the United Arab Emirates and Oman. Reading: Ithaca Press, 200 p.

Submitted March 31, 2014 Accepted April 6, 2014 


\section{Abstract}

This article advances the theoretical integration between securitization theory and the framing approach, resulting in a set of criteria hereby called security framing. It seeks to make a twofold contribution: to sharpen the study of the ideational elements that underlie the construction of threats, and to advance towards a greater assessment of the audience's preferences. The case study under examination is the 2011 military intervention of the countries of the Gulf Cooperation Council in Bahrain. The security framing of this case will help illuminate the dynamics at play in one of the most important recent events in Gulf politics.

Keywords: Gulf Cooperation Council; military intervention; security framing.

\section{Resumo}

Este artigo levanta a integração teórica entre a teoria da securitização e a abordagem de enquadramento, resultando num conjunto de critérios aqui chamado de enquadramento de segurança. Busca-se fazer uma contribuição em dois vieses: aguçar o estudo dos elementos ideacionais que subjazem a construção de ameaças e seguir rumo a uma avaliação das preferências da audiência. O estudo de caso examinado é a intervenção militar em 2011 dos países do Conselho de Cooperação do Golfo em Bahrain. O enquadramento de segurança deste caso ajudará a iluminar a dinâmica envolvida em um dos mais importantes eventos recentes na política do Golfo.

Palavras-chave: Conselho de Cooperação do Golfo; intervenção militar; enquadramento de segurança. 